\title{
Total Quality Management and Corporate Failure in Nigeria
}

\author{
Idam, Linus Egwu, Phd, Fnim \\ Adjunct Senior Lecturer Faculty Of Management Sciences, Ebonyi State University, Abakaliki, Nigeria
}

\begin{abstract}
The problem of corporate failure has continued to be of serious concern to academicians and practitioners, the world over. Of all the identified causal factors, management related factors are generally considered predominant. The search for management system that can effectively address the problem of corporate failure has led to the current interest of researchers and practitioners in total quality management $(T Q M)$. Research findings on the relationship between TQM and corporate performance have remained controversial across national boundaries and inconclusive in Nigeria. This paper investigated the relationship between identified critical success factors (CSFs) of TQM and elements of corporate performance in Nigeria, using Pearson product moment correlation technique in a 6-3 factorial design. The results of the factorial analysis showed positive and significantly high inter and intra-factorial correlation coefficient $(r)$ among the CSFs of TQM and elements of corporate performance at $p<0.05$. The hypotheses were tested by $t$ transformation of the correlation coefficient ( $r$ ). The results showed that implementation of the critical success factors of TQM will lead to enhanced return on investment, increase in asset base and greater market share of business organizations, and thus avert corporate failure in Nigeria.
\end{abstract}

Key words: Total quality management; corporate failure.

\section{Introduction}

The problem of corporate failure the world over has continued to be of serious concern to researchers, academicians, managers and operators both in the private and public sectors (Igwe, 1996; McRobert \& Hoffman, 1997). McRobert and Hoffman (1997) define corporate failure as inability of a corporate body to achieve a viable and sustainable economic mandate expressed in terms of minimum return required to keep the enterprise as a going concern, without a requirement for continual injections of additional funding. A firm is said to have failed if it is insolvent (Heffernan, 1996; McRobert \& Hoffman, 1997). A firm is insolvent when it has negative net assets; that is, its liabilities are in excess of the current value of its assets (Horne, 1980; Heffernan, 1996).

Corporate failure, particularly of key industries, precipitates a far-reaching multiplier effect, which negatively affects not only the stakeholders (shareholders, staff, suppliers, creditors etc.), but also the general economic health of the nation. In the international scene, the failure of such international organizations as Bank of Credit and Commerce International (BCCI) (1991), the Barrings of UK (1995) and the Canadian Commercial Bank (1985) had threatened the global economy (Heffernan, 1996)

In Nigeria, there have been serious cases of corporate failures. The banking sector alone recorded thirty-three cases between 1995 and 2000 (Central Bank of Nigeria, 2001). The manufacturing industry has witnessed cases of constant close down for reasons ranging from gross under capacity utilization to management ineptitude. Nine financial institutions were in recent past declared 'failed' by the Central Bank of Nigeria, resulting partly from inadequate capitalization and management related shortcomings.

Of all the causal factors in corporate failure identified by researchers and management consultants, which include, among others, management ineptitude, poor capitalization, staff related problems, environmental factors, macro socio-economic and political variables and technology, management related factors are considered predominant (McRobert \& Hoffman, 1997; Central Bank of Nigeria, 2001). Bibleault (1992) in his study came up with the assertion that $52 \%$ of corporate failures were caused by internally generated problems within management control.

In the last ten decades, a number of management systems have evolved in a bid to solve organizational problems. These include the Scientific Management of Frederick W. Taylor, the Administrative Management theory of Henri Fayol, the Human Relations School, pioneered by Elton Mayo and his associates at the Hawthorne experiments, the Behavioural Science theories, the Systems/Contingency theories and Management by Objectives, amongst others (Hicks \& Gullett, 1981). Each of the management systems has its merits and weaknesses and researchers have produced bewildering arrays of viewpoints and conclusions on their efficacy or otherwise in solving organizational problems.

The search for a management system that can effectively address the problem of corporate failure has led to the current interest of researchers and practitioners in Total Quality Management (TQM), one of the latest 
management philosophies rooted in integrative and collaborative efforts of organizational resources to continuously improve customer-focused services. The basic question now facing researchers is: Is TQM a panacea for persistent corporate failures, or is it merely adding to the list of management theories, and thus deepening what Koontz and O'Donnell (1976) described as "management theory jungle"? This paper attempts to investigate the relationship between TQM and corporate performance in Nigeria.

\section{i. The Concept of Total Quality Management (TQM)}

\section{Literature Review}

Varying views and shades of opinion have been expressed by academicians and practitioners over the concept and definition of TQM. Bounds, Yorks, Adams \& Ranney (1994) adduce three reasons for this disagreement. The first is that TQM is an evolving concept, which changes as new ideas and methods are developed. The second reason is that different organizations are at different stages of transforming to TQM; and thirdly, different organizations may require different forms of TQM. Bounds et al. (1994) assert that TQM is not just another programme, nor is it just a managerial style or motivational gimmick for adoption by organizations. They rather see TQM, in the light of a paradigm shift, as a cultural transformation that is driven by the redefinition of roles and focus of organizational members.

Various TQM advocates have developed different models arising from differences in concept and definition of total quality management. Thus Deming (1986) in his 'management model', places emphasis on the commitment of management to TQM, as a crucial success factor. Deming $(1982,1986,1993)$ formulated a quality management theory based on system improvement, the reduction of variations to meet customer requirements and the humane and proper management of people. He postulated that significant part of organizational pathology was caused by management inability to manage effectively.

Deming, generally revered as the father of Japanese quality management, articulated fourteen points for management, insisting that management must assume leadership and take responsibility for organizational performance. His teaching, embodied in the Plan, Do, Check and Act (PDCA) circle is referred to as 'Deming Circle'. He criticized the concept of acceptable quality level, which carried the assumption that some level of defects was good enough.

Crosby $(1979,1984)$ has a quality model, which views quality in terms of conformance to requirements and design specifications. Crosby defines TQM as a quality system philosophy concerned with doing things right, first time and always, which adds nothing to the cost of a company's products or services. He was a leading advocate of zero defect concept and, like Deming, was critical of the concept of acceptable quality level.

Juran $(1964,1989,1992)$ conceptualizes 'quality' in terms of fitness for use or purpose and asserts that TQM is concerned with standard for continuous improvement, with commitment to customers' satisfaction. To him quality can only be determined by the user, not the manufacturer. He defines 'users' as not only the ultimate consumers, but include all those involved in handling the product. Juran places emphasis on managerial responsibility for improvement to meet customers' needs, thus sharing the same view with Deming $(1982,1986$, 1993). Juran (1992) developed what is known as 'Juran's Trilogy', an approach to cross-functional management that is composed of three managerial processes of planning, control and improvement.

Ishikawa (1985) developed a "person-centred" model, which places emphasis on development of organizational human resources, as a fundamental means of pursuing continuous quality improvement. He advocated the focus of investigative efforts in addressing quality problems on determination of causal factors. Feigenbaum $(1983,1991)$ stresses the importance of top management commitment, and the need for customeroriented quality management system, based on inter-departmental and cross-functional relationship.

Oakland (2000) views TQM as an approach to improving the competitiveness and flexibility of an organization, and essentially involving individuals at all levels in planning, organizing, controlling and understanding organizational activities. Oakland asserts that TQM is user-driven, concerned with moving the focus of control from outside the individual to within, in a bid to ensuring accountability and commitment. He agrees with Crosby (1979), Mead (1990), Collard (1989) and Bounds et al. (1994) that TQM is culture driven, concerned with changing attitudes and skills so that the culture of the organization becomes one of preventing failure and doing the right things, first time, every time.

TQM is holistic in concept and approach. Contextually, the word "total" conveys the idea that every organization member in every functional unit and level throughout the organization accepts and pursues quality. The word "quality" connotes excellence in every aspect of the organization and covers quality of products, quality of production processes and system, quality of personnel, service delivery, customer satisfaction and cost effectiveness. The word "management" refers to the pursuit of quality results through a quality management process. 


\section{ii. Economic Value of TQM}

In the literature, advocates of total quality management have canvassed its far reaching impact on organizational performance (Chen, Yu \& Chang, 2005; Prajogo \& Sohal, 2006; Fotopoulos \& Psomas, 2009). TQM is credited with leading Japan to global economic prominence in the post war years (Iman, 1986). TQM is similarly credited with restoring America's economic competitiveness (Juran, 1993). Adherents claim that TQM can be successfully implemented in any organization to improve quality of goods and services, reduce costs, achieve higher level of customer satisfaction and employee commitment and improve financial performance (Powell, 1995; Juran, 2001; Davies, 2003).

Hassan, Mukhtar, Qureshi and Sharif (2010) investigated the impact of TQM practices on quality performance, business performance and organizational performance of Pakistani manufacturing firms located in six big industrial cities. Their study came up with the findings that greater degree of implementation of TQM practices results in higher quality performance, business performance and organizational performance.

However, the value of TQM in solving organizational problems has remained controversial. While some studies established positive relationship of TQM with organizational performance (Easton \& Jurrell, 1998; Hendricks \& Singhal, 2001a,b), some reported negative relationship (Chapman, Murray \& Mellor, 1997). Yet some studies reported non-existent relationship of financial returns with TQM (Adams, 1994; Powell, 1995; York \& Miree, 2004).

Critics argue that TQM demands unrealistic amount of management time, involves excessive costs, in terms of retraining and increased paperwork and calls for unsustainable level of employee commitment. They also aver that TQM emphasizes process over results and fails to address the needs of small firms, service organizations and non profits (Schaffer \& Thomson, 1992; Powell, 1995).

Santos-Vijande and Alvarez-Gonzalez (2007) attribute the conflicting reports of research findings on the relationship of TQM with corporate performance to differences in methodology and conceptual approaches used by researchers. Barney (1991) explains the differences in terms of variations in organizational resources. The resource-based theory of TQM as a competitive advantage introduces the notion of resource heterogeneity, which means that different organizations hold different resource portfolio. These differences, according to the theory, produce variability in performance across organizations. Resource bundles are heterogeneous because of their imperfect imitability (Barney, 1991; Peteraf, 1993; Powell, 1995).

Santos-Vijande and Alvarez-Gonzalez (2007) highlight a new body of research, which focuses on contingency approach to the relationship of TQM with business performance. The approach assumes that the effect of TQM on business results is conditional upon both external uncontrollable environmental forces as well as internal organizational factors, such as firm size, capital base and level of operationalization of TQM (Hendricks \& Singhal, 2001a; Taylor \& Wright, 2003).

\section{iii. TQM Critical Success Factors (CSFs)}

Jha and Kumar (2010) defined critical success factors (CSKs) in the context of TQM as key dimensions that are critical to the successful implementation of total quality management. In the literature, various critical success factors have been identified. However, various frameworks have produced varying sets of critical success factors (Saraph, George \& Schroeder, 1989; Powell, 1995; Flynn, Schroeder \& Sakakibara, 1995; Silas \& Ebrahimpour, 2002; Jha \& Kumar, 2010).

Silas and Abrahimpour (2002) adduce three reasons to justify the appearance of different sets of critical success factors in the literature. The first is that differences arise from the conceptual approaches adopted by various researchers. The second is the differences in the empirical methodology. While some researchers use factor analysis, others use confirmatory factor analysis. The third reason is that differences exist in the sociocultural, economic and political environments in various nations, where studies on TQM implementation have been carried out. These differences, Silas and Ebrahimpour (2002) argue, create problem of adoptability and transferability of TQM concepts, principles and practices.

Jha and Kumar (2010) reviewed fourteen frameworks from literature and came up with ten critical success factors for the construction industry. These include: Corporate quality culture, Strategic quality management, Quality improvement measurement system, People and customer management, Operational quality planning, External interface management, Supplier's partnership, Teamwork structures, Customer satisfaction orientation and communication of improvement information.

Powell (1995), drawing from the resource approach and other theoretical perspectives, examines TQM as a potential source of sustainable competitive advantage. His findings suggest that most features and dimensions considered as critical success factors in TQM implementation, such as quality training, process improvement and benchmarking, do not generally produce advantage. He contends that certain tacit, behavioural and imperfectly imitable features, such as open culture, employee empowerment and executive commitment, rather produce advantage. Powell (1995) draws the conclusion that these tacit resources, rather than TQM tools and techniques, drive TQM success, and that organizations that acquire them can outperform 
competitors, with or without the accompanying TQM tools and techniques.

Based on literature review and from preliminary survey of Nigeria's corporate bodies, six dimensions or critical success factors most relevant in Nigeria include: (1) Leadership commitment, (2) Continuous improvement, (3) Teamwork, (4) Customer focus, (5) Employee empowerment and (6) Organizational culture and environment (Internal environment).

Leadership commitment is widely believed to be a crucial element in a successful implementation of total quality management across geographical and cultural settings (Deming, 1986; Flynn, Schroeder \& Sakakibara, 1995; Soltani, 2005). For a successful implementation of TQM, management must show sustained interest, provide conducive operational environment and provide resources required for necessary staff training and empowerment.

Advocates of total quality management consider continuous improvement as a fundamental dimension, necessary for successful implementation of TQM (Deming, 1982; Imai, 1986; Bounds et al., 1994; Oakland, 2000). Continuous improvement is conceptualized as a never ending effort by every member of the organization to continually improve on the quality of goods and services along the line dictated by customers' requirements (Oakland, 2000). Continuous improvement is generally associated in the literature with Japanese 'kaizen' philosophy of long term incremental improvement involving all employees in an organization, committed to perform their tasks a little better each day (Imai, 1986; Bounds et al., 1994).

Imai (1986) criticizes the re-engineering (innovation) approach of the West, which involves enormous expenditure on research and development to achieve major technological advances. On account of cultural and environmental differences, this paper advocates, for Nigerian organizations, the adoption of continuous improvement as defined by Bounds et al. (1994) as

"The combination of kaizen and innovation such that between the big jumps (innovation) repeated small steps (kaizen) would ensure perpetual progress with no backsliding”. (p.69).

For a successful implementation of TQM in any organization, teamwork is generally considered a critical factor (Scott \& Jaffe, 1997; Oakland, 2000). Teamwork is conceptualized as the working together of organizational members in a collaborative effort to solve organization's problems for the benefit of customers. Teamwork produces synergistic effect such that the team is much more than the collection of individual members. Teamwork builds trust, improves cross-functional communication and fosters interdependence (Oakland, 2000).

Customer focus is another important critical factor in the successful implementation of TQM. Oakland (2000) asserts that meeting customer requirement is central to the entire concept of quality management. Deming (1982) argues that quality should be conceived in the light of the present and future customers' requirements, while the 'fit for use' imperative of Juran (1989) underscores the importance of customers in determining quality management strategies. Oakland (2000) insists that quality starts with understanding of customers' needs and ends when those needs are satisfied.

Employee empowerment constitutes an indispensable element in successful TQM implementation (Crosby, 1979; Ishikawa, 1985). Organizational human resources require to be properly empowered through adequate training and development, and by effective system of rewards and recognition, in order to elicit their cooperation and commitment indispensable for successful implementation of TQM.

Finally, the importance of organizational culture and environment in the successful implementation of TQM is increasingly identified in the literature (Barney, 1991; Bounds et al., 1994; Oakland, 2003; Rad, 2006). Organizational culture is defined as both visible and invisible elements, including physical and technological factors, beliefs and norms, which are shared by members of an organization, and which enable the organization to solve both internal and external work related problems. (Bounds et al., 1994).

Organizational culture is closely related to environment, which can be defined as the totality of all the physical, socio-cultural, political, religious and technological factors, which directly and indirectly affect the operations of an organization. Silas and Ebrahimpour (2002) argue that differences in organizational culture and environment create problem of adoptability and transferability of TQM principles and practices. Bounds et al. assert that TQM is culture driven and successful implementation must reflect the cultural and environmental setting of the organization. This paper agrees with their assertion. In this study, internal environment is used for organizational culture and environmental elements within the control of management.

\section{Relevant Empirical Studies in Nigeria}

A number of empirical studies have been carried out to investigate the relationship of TQM and corporate performance in Nigeria. A study by Nnedum (2001) investigated the relationship between TQM and job satisfaction in some industrial organizations in Nigeria. The study was based on assumptions, among others, that every organization is evolving from the 'pyramid' to the 'cycle style' of organization structure. From the test of his hypotheses, Nnedum (2001) came up with the findings that there existed positive correlation between TQM dimensions and job satisfaction. 
However, job satisfaction, which has to do with staff morale and motivation at work, does not necessarily guarantee corporate success, nor does job dissatisfaction necessarily lead to corporate failure. Nnedun (2001) examined only three dimensions regarded as critical success factors namely, continuous improvement, customer focus and teamwork. He could not identify other critical success factors that accounted for his findings. There is therefore the need for further research to establish the relationship between relevant TQM critical success factors and corporate performance in Nigeria.

Eziashi (1999) carried out a study of TQM as panacea for instability and stagnation of firms in a competitive industry, using Agip Nig. Plc and UBA Plc as a case study. He came up with the conclusion that TQM was positively associated with industrial growth and stability. Eziashi (1999), however, failed to highlight the critical success factors of TQM that were implemented by the companies studied. In another study, Chikwendu (2001) investigated the level of application and impact of TQM in banking organizations in Nigeria, using First Bank of Nigeria Plc, Diamond Bank Ltd and All States Trust Bank Plc (now defunct). His conclusion that TQM was fully implemented in the three banks was based on inadequate analysis. He equally did not show the critical success factors of TQM that were implemented.

From the above, it can be stated that empirical research on the relationship of TQM and corporate performance in Nigeria is inconclusive. This is the justification for the present study.

\section{Hypotheses}

Based on the preliminary studies carried out by the researcher and from the review of related literature on the subject, the following hypotheses are tested for their statistical significance. They are all null hypotheses:

1. There is no positive relationship between level of leadership commitment and corporate performance, reflected by net return on investment, asset base and market share.

2. There is no positive relationship between level of continuous improvement and corporate performance, reflected by net return on investment, asset base and market share.

3. There is no positive relationship between degree of teamwork and corporate performance, reflected by net return on investment, asset base and market share.

4. There is no positive relationship between extent of customer focus and corporate performance, reflected by net return on investment, asset base and market share.

5. There is no positive relationship between level of employee empowerment and corporate performance, reflected by net return on investment, asset base and market share.

6. There is no positive relationship between quality of internal environment and corporate performance, reflected by net return on investment, asset base and market share.

7. There is no positive relationship between TQM and corporate performance of a business organization.

\section{Research Methodology}

The population of this study consists of all business organizations in Nigeria that have either implemented formal TQM programme, or adopted TQM principles for at least two years, and have been accredited as quality-driven organizations. To qualify for inclusion, a business organization must be winners of both International Standard Organization (ISO) certificate and Nigerian Industrial Standards (NIS) certificate in the Diamond and Gold categories for two consecutive years (2010-2011). A list of such organizations were obtained from the directories of International Standards Organization (ISO) and Standard Organization of Nigeria (SON). Similar studies carried out in Palestine (Baidoun \& Zairi, 2003) and in Australia (Prajogo \& Brown, 2004) confirm the suitability of this selection process.

From the twenty seven qualified organizations, twenty five companies were randomly selected for the study, using the Yaro Yamane formula for finite population at the 5\% level of significance. From a total staff strength of 8,730 employees of the 25 companies, the sample size of 382 was chosen, also using the Yaro Yamane formula for finite population at the $5 \%$ level of significance. Individual participants in the various organizations were randomly selected from the list obtained from their personnel departments.

A $6 \times 3$ factorial design was adopted to assess the relationship between the independent variables (factor A) and dependent variables (factor B). Factor A consists of six TQM CSFs: Leadership commitment (A1), Continuous improvement (A2), Teamwork (A3), Customer focus (A4), Employee empowerment (A5) and Internal environment (A6). Components of Factor B (corporate performance) are: Net return on investment (B1), Asset base (B2) and Market share (B3).

The hypotheses of study, as stated above, seek to establish that a positive relationship exists between TQM and corporate performance and that the individual critical success factors of TQM have positive relationship with individual elements of corporate performance. The validity and test of reliability of the research instrument, consisting of 30-item scale, were carried out in two phases.

The first phase involved the use of management experts in tertiary institutions and professionals with manifest interest in TQM to assess the relevance of the items included in the research instrument. The second 
phase was a pilot study to test the reliability of the instrument, using test-retest method on a small sample of three participating business organizations. The two sets of data collected were analyzed and correlated, using the Pearson-product moment correlation technique. The resulting correlation coefficient, $r=0.946$ is significantly high at $\mathrm{p}<.01$ and compares favourably with the conventionally acceptable standard of reliability, $\mathrm{r}=0.74$ (Morrow, 1997).

Data collected were analyzed to establish the relationship among independent and dependent variables, using the Pearson-product moment correlation technique. The hypotheses under study were tested by ttransformation of the correlation coefficient

$(\mathrm{r})$.

\section{Results}

Results are presented in relation to factorial analysis and in relation to the study hypotheses. Items relevant to the independent and dependent variables were grouped together for the purpose of factorial analysis. The Pearson Product Moment Correlation technique was used to determine and analyze the inter-factorial relationship of the predictor and criterion variables. The Pearson correlation matrix is shown in table 1 below.

Table 1: Pearson Factorial Correlation Matrix

\begin{tabular}{|l|l|l|l|l|l|l|l|l|l|}
\hline & A1 & A2 & A3 & A4 & A5 & A6 & B1 & B2 & B3 \\
\hline A1 & 1 & & & & & & & & \\
\hline A2 & 0.981 & 1 & & & & & & & \\
\hline A3 & 0.991 & 0.998 & 1 & & & & & & \\
\hline A4 & 0.983 & 0.919 & 0.955 & 1 & & & & & \\
\hline A5 & 0.986 & 0.922 & 0.967 & 0.992 & 1 & & & & \\
\hline A6 & 0.988 & 0.896 & 0.911 & 0.983 & 0.952 & 1 & & & \\
\hline B1 & 0.984 & 0.931 & 0.952 & 0.997 & 0.961 & 0.992 & 1 & & \\
\hline B2 & 0.916 & 0.821 & 0.855 & 0.980 & 0.896 & 0.924 & 0.973 & 1 & \\
\hline B3 & 0.998 & 0.971 & 0.983 & 0.987 & 0.991 & 0.986 & 0.993 & 0.934 & 1 \\
\hline
\end{tabular}

Level of Significance $=p<.05$

From the table, the correlation coefficient ( $r$ ) of leadership commitment (factor A1) and net return on investment (factor B1) is not only positive, but significantly high at $r=0.984, p<.05$. Similarly, all the interfactorial correlation coefficients of the other components of the independent and dependent variables as reported in table 1 are positively and significantly high, the lowest coefficient being that of continuous improvement (A2) and asset base (B2), at $\mathrm{r}=0.821$.

Additionally, the analysis reported high intra-factorial correlation coefficients among the components of both the independent and dependent variables. Thus the components of independent variables recorded a range of coefficients from $r=0.998$ for A2A3 to $r=0.896$ for A2A6 at $p<.05$. Similarly, the intra-factorial correlation coefficients of the three components of the dependent variables were significantly high at $r=0.973$ for B1B2; $r=0.993$ for B1B3 and $r=0.934$ for B2B3, all at $p<.05$. These high intra-factorial correlation coefficients confirm mutual consistency and stability among the component variables.

The Pearson product moment correlation coefficient ( $r$ ) was used to test the hypotheses. The use of Pearson correlation coefficient ( $r$ ) for the purpose of testing hypotheses requires transformation of the coefficient ( $r$ ) into student-t statistic, using transformation formula:

$\operatorname{tr}=\underline{\mathrm{r} \sqrt{ } \mathrm{N}-2}$

$$
1-\mathrm{r}^{2} \quad \text { where }
$$

$\operatorname{tr}=\mathrm{t}$ value of transformed correlation coefficient $(r)$,

$\mathrm{N}-2=$ the degree of freedom,

$\mathrm{r}^{2}=$ the coefficient of determination.

The related statistics are summarized in table 2 below.

Table 2: Transformed Pearson Correlation Coefficient ( $r$ ) to t statistic (tr) in Relation to the Hypotheses

\begin{tabular}{|l|l|l|l|l|l|}
\hline Ho & Variables & $\mathbf{r}$ & $\mathbf{r}^{2}$ & tr (Cal) & t (table) \\
\hline 1 & $\mathrm{a} 1 \mathrm{~b} 1$ & 0.984 & 0.968 & 9.603 & 2.353 \\
\hline & $\mathrm{a} 1 \mathrm{~b} 2$ & 0.916 & 0.839 & 3.960 & 2.353 \\
\hline & $\mathrm{a} 1 \mathrm{~b} 3$ & 0.998 & 0.997 & 33.920 & 2.353 \\
\hline & $\mathrm{a} 2 \mathrm{~b} 1$ & 0.931 & 0.868 & 4.430 & 2.353 \\
\hline & $\mathrm{a} 2 \mathrm{~b} 2$ & 0.821 & 0.674 & 3.360 & 2.353 \\
\hline & $\mathrm{a} 2 \mathrm{~b} 3$ & 0.971 & 0.942 & 6.975 & 2.353 \\
\hline 3 & $\mathrm{a} 3 \mathrm{~b} 1$ & 0.952 & 0.907 & 5.398 & 2.353 \\
\hline & $\mathrm{a} 3 \mathrm{~b} 2$ & 0.855 & 0.731 & 2.853 & 2.353 \\
\hline & $\mathrm{a} 3 \mathrm{~b} 3$ & 0.983 & 0.967 & 13.200 & 2.353 \\
\hline
\end{tabular}




\begin{tabular}{|l|l|l|l|l|l|}
\hline 4 & $\mathrm{a} 4 \mathrm{~b} 1$ & 0.997 & 0.994 & 22.281 & 2.353 \\
\hline & $\mathrm{a} 4 \mathrm{~b} 2$ & 0.980 & 0.960 & 8.485 & 2.353 \\
\hline & $\mathrm{a} 4 \mathrm{~b} 3$ & 0.987 & 0.974 & 10.517 & 2.353 \\
\hline 5 & $\mathrm{a} 5 \mathrm{~b} 1$ & 0.961 & 0.924 & 9.503 & 2.353 \\
\hline & $\mathrm{a} 5 \mathrm{~b} 2$ & 0.896 & 0.803 & 3.970 & 2.353 \\
\hline & $\mathrm{a} 5 \mathrm{~b} 3$ & 0.991 & 0.982 & 14.252 & 2.353 \\
\hline 6 & $\mathrm{a} 6 \mathrm{~b} 1$ & 0.992 & 0.984 & 16.198 & 2.353 \\
\hline & $\mathrm{a} 6 \mathrm{~b} 2$ & 0.924 & 0.854 & 5.784 & 2.353 \\
\hline & $\mathrm{a} 6 \mathrm{~b} 3$ & 0.986 & 0.972 & 12.456 & 2.353 \\
\hline & $\mathrm{a} 1,2,3,4,5,6$ & 0.978 & 0.956 & 8.611 & 2.353 \\
\hline 7 & $\mathrm{~b} 1,2,3$ & & & \\
\hline
\end{tabular}

Level of significance: 0.05 ; df: 3

Decision rule was to reject the null hypotheses if the calculated $t(t)$ was greater than the critical value of $t$ at 0.05 level of significance, at three degrees of freedom (df). Otherwise the null value would be accepted. From table 2, the value of the transformed correlation coefficient (tr) range from 33.920 to 2.853, all above the critical value of $t=2.353$ at 0.05 level of significance and three degrees of freedom.

It follows that all the null hypotheses, as listed in section $\mathrm{V}$, were rejected and their alternatives accepted. In other words, there existed significant positive relationship between individual critical success factors of TQM and each of the three identified elements of corporate performance, as well as all the variables of TQM taken together and corporate performance.

The implication is that implementation of the critical success factors of TQM will lead to enhanced return on investment, increase in asset base and greater market share of business organizations, and thus avert corporate failure in Nigeria. The findings supported earlier studies on the economic values of TQM (Imai, 1986; Easton \& Jurrell, 1998; Hendricks \& Singhal, 2001a,b; Chen, Yu \& Chang, 2005; Feng, Prajogo \& Sohal, 2006; Fotopoulos \& Psomas, 2009).

\section{Conclusions}

\section{Conclusions and Recommendations}

From the findings, it can be concluded that Nigerian business organizations need to embrace and implement the critical success factors of TQM, in order to avert corporate failure. Effective implementation demands that management must show sustained commitment to TQM and provide suitable working environment that will promote the desirable organizational culture. Adequate employee empowerment and well coordinated teamwork are other critical elements that will ensure that quality of customer-focused goods and services are continuously improved to meet the needs of present and future customers. Full implementation of TQM will ensure sustained profitability and increase the organization's asset base and market share, thereby averting corporate failure.

\section{Recommendations}

In the light of the foregoing conclusions, the following recommendations are made:

1. Top management of Nigerian business organizations should install effective programmes of training and orientation of their staff to inculcate in them the spirit of teamwork and maintenance culture, necessary for effective implementation of TQM. Top management should also strive, through positive reinforcement, to involve staff at all levels in decision making and implementation of decisions. Effort should be made to integrate organizational corporate objectives with staff personal objectives. This will enable staff to have a sense of belonging, and to see the realization of corporate objectives as a necessary means of achieving their personal objectives.

2. There should be proper coordination among departmental and cross-functional teams to continually determine ever changing customers' requirements and to evolve strategies that will ensure continuous improvement of the quality of goods and services to the satisfaction of present and future customers.

\section{References}

[1]. Adam-Jr, E .E. (1994). Alternative quality improvement practices and organizational performance. Journal of Operations Management, 12(1), 27-44.

[2]. Baidoun, S. \& Zairi, M. (2003). A proposed model of TQM implementation in the Palestinian context. TQM and Business Excellence, 14(10), 1193-1211.

[3]. Barney, J. (1991). Firm resources and sustained comparative advantage. Journal of Management. 17, 99-120.

[4]. Bibleault, D. B. (1992). Corporate turnaround: How managers turn losers into winners. New York, NY: McGraw Hill.

[5]. Bounds, G., Yorks, L.,Adams, M. \& Ranney, G. (1994). Beyond total quality management towards the emerging paradigm. New York, NY: McGraw Hill.

[6]. Central Bank of Nigeria (2001). Banking Supervision Annual Report. CBN, Abuja, Nigeria. Author.

[7]. Chapman, R. L., Murray, P. C. \& Mellor, R. (1997). Strategic quality management and financial performance indicators. International Journal of Quality and Reliability Management, 14(4), 432-448. 
[8]. Chen, C. R., Yu, C. H. \& Chang, H. C. (2005). An empirical analysis of customer-oriented service activities in the Taiwanese public sector. Total Quality Management and Business Excellence, 16(7), 887-901.

[9]. Chong, V. K. \& Rudus, M. J. (2004). Total quality management, market competition and organizational performance. British Accounting Review, 36(2), 155-172.

[10]. Collard, R. (1989). Total quality success through people. London, U.K.: Institute of Personnel Management.

[11]. Crosby, P. B. (1979). Quality is free $\left(2^{\text {nd }}\right.$ ed.). New York, NY: McGraw Hill.

[12]. Crosby, P. B. (1984). Quality without tears: The art of hassle-free management. New York, NY: McGraw Hill.

[13]. Deming, W. E. (1982). Quality, productivity and competitive position. Cambridge, Mass: Massachusetts Institute of Technology.

[14]. Deming, W. E. (1986). Out of the crises. Cambridge, Mass: Massachusetts Institute of Technology.

[15]. Deming, W. E. (1993). The new economics. Cambridge, Mass: Massachusetts Institute of technology.

[16]. Easton, G. S. \& Jarrell, S. L. (1998). The effects of total quality management on corporate performance: An empirical investigation. Journal of Business, 71(2), 253-307.

[17]. Feigenbaun, A. V. (1983, 1991). Total quality control. New York, NY: McGraw Hill.

[18]. Feng, J., Prajogo, D. I. \& Sohal, A. S. (2006). The impact of TQM practices on performance: A comparative study between Australian and Singaporean organizations. European Journal of Innovation Management, 9(3), 269-278.

[19]. Flynn, B. B., Schroeder, R. G. \& Sakakibara, S. (1995). The impact of quality management practices on performance and competitive advantage. Decision Sciences, 26(5), 659-691.

[20]. Fotopoulos, C. B. \& Psomas, E. L. (2009). The impact of soft and hard TQM elements on quality management results. International Journal of Quality and Reliability management, 26(2), 150-163.

[21]. Hassan, M. U., Mukhtar, A., Qureshi, S. U. \& Sharif, S. (2012, October). Impact of TQM practices on firm's performance of Pakistan's manufacturing organizations. International Journal of Academic Research in Business and Social Sciences, 2(10), 232259.

[22]. Heffernan, S. (1996). Modern banking in theory and practice. New York, NY: John Wiley and Sons.

[23]. Hendricks, K. B. \& Singhal, V. R. (2001a). Firm characteristics, total quality management and financial performance. Journal of Operations Management, 19(3), 269-285.

[24]. Hendricks, K. B. \& Singhal, V. R. (2001b). The long-run stock price performance of firms with effective TQM programs. Management Science, 47(3), 359-368.

[25]. Horne, J. C. V. (1980). Financial management and policy. London, U.K: Prentice-Hall International.

[26]. Igwe, I. (1996). Public enterprise management: A proposal for improvement performance assessment. ASCON Journal of Management, 15(1), 1-12.

[27]. Imai, M. ((1986). Kaizen: The key to Japanese competitive success. New York, NY: McGraw Hill.

[28]. Ishikawa, K. (1985). What is total quality? The Japanese way. N.J: Prentice Hall.

[29]. Jha, U. C. \& Kumar, S. (2010). Critical success factors of TQM: A literature review and analysis. Oxford Business and Economic Conference Program. Retrieved from: gcbe.us/2010_OBSC/data/U.C.\%20Jha\%20Kumar.doc.

[30]. Juran, J. M. (1964). Managerial breakthrough: A new concept of the manager's job. New York, NY: McGraw Hill.

[31]. Juran, J. M. (1989). Quality control handbook. New York, NY: McGraw Hill.

[32]. Juran, J. M. (1992). Juran on quality by design: The new steps for planning quality into goods and servives. New York, NY: The Free Press.

[33]. Juran, J. M. (2001). Juran's quality handbook. Blacklick, OH: McGraw Hill.

[34]. Koontz, H. \& O’Donnell, C. (1976). Management systems and contingency analysis. Kogakusha, Tokyo: McGraw Hill.

[35]. McRobert, A. \& Hoffman, R. (1997). Corporate collapse: An early warning system for lenders, investors and suppliers. Sydney, Australia: McGraw Hill.

[36]. Mead, R. (1990). Cross-cultural management communication. Chichester, U.K: John Wiley and Sons.

[37]. Morrow, P. C. (1997). The measurement of TQM principles and work related outcome. Journal of Organizational Behaviour, 18, $363-376$.

[38]. Nnedum, U. O. A. (2001). Total quality management and job satisfaction in some industrial organizations in Nigeria. Unpublished M.Sc. Dissertation, University of Jos, Nigeria.

[39]. Oakland, J. (2000). Total quality management ( $2^{\text {nd }}$ ed.). Oxford, U.K: Butterworth Heinemann.

[40]. Oakland, J. (2003). Total quality management: Text with cases ( $3^{\text {rd }}$ ed.). Oxford, U.K: Butterworth Heinemann.

[41]. Peteraf, M. (1993). The cornerstones of competitive advantage: A resource- based view. Strategic Management Journal, 14(3), 179191.

[42]. Powell, T. C. (1995). Total quality management as competitive advantage: A review and empirical study. Strategic Management Journal, 16, 15-37.

[43]. Prajogo, D. I. \& Brown, A. (2004). The relationship between TQM practices and quality performance and the role of formal TQM programmes: An Australian empirical studies. Quality Management Journal, 11(4), 31-42.

[44]. Rad, A. M. M. (2006). The impact of organizational culture on the successful implementation of total quality management. The TQM Magazine, 18(6), 606-625.

[45]. Santos-Vijande, M. L. \& Alvarez-Gonzalez, L. I. (2007). TQM and firm performance: An EFQM excellence model research-based survey. International Journal of Business Science and Applied Management, 2(2), 21-41.

[46]. Saraph, J. V. P., George, B. \& Schroeder, R. G. (1989). An instrument for measuring the critical factors of quality management. Decision Sciences, 20(4), 457-478.

[47]. Schaffer, R. \& Thomson, H. (1992, Jan-Feb.).Successful change programs begin with results. Harvard Business Review, pp 80-89.

[48]. Scott, C. D. \& Jaffe, D. I. (1997). Employment building, a committed workforce (6 ${ }^{\text {th }}$ ed.). London, U.K.: Kogan Page.

[49]. Silas, I. \& Ebrahimpour, M. (2002). An investigation of total quality management survey-based research published between 1989 and 2000: A literature review. International Journal of Quality and Reliability Management, 19(7), 902-970.

[50]. Soltani, E. (2005). Top management: A threat or an opportunity to TQM? Total Quality Management, 16(4), 463-476.

[51]. Taylor, W. A. \& Wright, G. H. (2003). A longitudinal study of TQM implementation: Factors influencing success and failure. Omega, 3, 170-188.

[52]. York, K. M. \& Miree, C. E. (2004). Causation or covariance? A empirical re-examination of the link between TQM and financial performance. Journal of Operations Management, 22, 291-311. 


\begin{abstract}
About the Author
Dr. Idam, Linus Egwu is an Adjunct Senior Lecturer in the Faculty of Management Sciences, Ebonyi State University, Abakaliki, Nigeria. He obtained his BSc. (Second Class Upper Division) in Economics from the University of Ibadan in 1977. He got his MBA in Management from the University of Nigeria, Nsukka in 1987 and $\mathrm{PhD}$ in Management from Ebonyi State University in 2007. He is a Fellow of the Nigerian Institute of Management (Chartered) and the Pioneer Chairman of Ebonyi State Chapter of the Institute.

Dr. Idam, a former Senior Manager of United Bank for Africa Plc, was the founding Head of the Department of Banking and Finance, Ebonyi State University, Abakaliki and also served the University as Dean of the Faculty of Management Sciences and Director of the University Consultancy Services, amongst other responsibilities. $\mathrm{He}$ is currently serving Ebonyi State Government as a Commissioner in the State Fiscal Responsibility Commission.
\end{abstract}

